\title{
Emended descriptions of the genus Lewinella and of Lewinella cohaerens, Lewinella nigricans and Lewinella persica, and description of Lewinella lutea sp. nov. and Lewinella marina sp. nov. \\ Correspondence \\ Shams Tabrez Khan \\ shams-tabrez-khan@nite.go.jp

\author{
Shams Tabrez Khan, Yukiyo Fukunaga, Yasuyoshi Nakagawa \\ and Shigeaki Harayama
} \\ NITE Biological Resource Center (NBRC), National Institute of Technology and Evaluation (NITE), 2-5-8 Kazusakamatari, Kisarazu, Chiba 292-0818, Japan

\begin{abstract}
Two strains, MKG-38 ${ }^{\top}$ and $\mathrm{FYK} 2402 \mathrm{M}^{\top} 9^{\top}$, were isolated from a marine sediment sample and a sea snail, respectively, both collected on the Pacific coast of Japan. Phylogeny of these new isolates based on 16S rRNA gene sequences indicated that they are members of the genus Lewinella. Morphological, physiological and biochemical properties of these two isolates, together with the type strains of the three previously described species of the genus Lewinella, were characterized. The new isolates were Gram-negative, aerobic, rod-shaped, chemo-organotrophic and able to degrade starch and $\mathrm{CM}$-cellulose. A comparative polyphasic study showed that these two isolates represent two novel species of the genus Lewinella, for which the names Lewinella marina sp. nov. (type strain, MKG-38 ${ }^{\top}=\mathrm{NBRC} 102633^{\top}=\mathrm{NCIMB} 14312^{\top}$ ) and Lewinella lutea sp. nov. (type strain, FYK2402M69 ${ }^{\top}=\mathrm{NBRC} 102634^{\top}=\mathrm{NCIMB} 14313^{\top}$ ) are proposed. Emended descriptions of the genus Lewinella (Sly et al. 1998) and of Lewinella cohaerens, Lewinella nigricans and Lewinella persica are also proposed.
\end{abstract}

Lewin (1970) described three novel marine species of the genus Herpetosiphon, namely Herpetosiphon cohaerens, Herpetosiphon nigricans and Herpetosiphon persicus, based on phenotypic characteristics. Later, 16S rRNA gene sequences of these strains were determined and a novel genus, Lewinella, in the family 'Saprospiraceae' was created for these strains (Sly et al., 1998). In this paper, we describe the characterization of two strains isolated on the Pacific coast of Japan; strain MKG- $38^{\mathrm{T}}$ was isolated from a marine sediment sample collected at Kamogawa, whilst strain FYK $2402 \mathrm{M}^{2} 9^{\mathrm{T}}$ was isolated from a sea snail (Nodilittorina trochoides) collected from Mikurajima. Polyphasic characterization of the new isolates, together with the type strains of previously described species of the genus Lewinella, was performed. Based on their phenotypic traits and phylogenetic positions, we propose that the two new isolates represent novel species of the genus Lewinella.

The GenBank/EMBL/DDBJ accession numbers for the 16S rRNA gene sequences of Lewinella marina $\mathrm{MKG}-38^{\top}$, Lewinella lutea FYK2402M69 ${ }^{\top}$, Lewinella cohaerens $I-2^{\top}$, Lewinella nigricans SS-2 ${ }^{\top}$ and Lewinella persica $\mathrm{T}-3^{\top}$ are AB301495, AB301494, AB301614, AB301615 and AB301616, respectively.

Electron micrographs showing morphology of members of the genus Lewinella and a supplementary table showing pairwise 16S rRNA gene sequence similarities are available with the online version of this paper.
Strains MKG-38 ${ }^{\mathrm{T}}$ and FYK2402M69 ${ }^{\mathrm{T}}$ formed light-orange and dark-orange colonies, respectively, on half-strength marine agar (HSMA) plates (Marine Agar 2216; Difco) after 3-4 days incubation at $25{ }^{\circ} \mathrm{C}$. Strains were maintained on HSMA plates and stored at $-80{ }^{\circ} \mathrm{C}$ in artificial seawater (ASW; Naigai Chemicals) containing $20 \%(\mathrm{v} / \mathrm{v})$ glycerol.

For $16 \mathrm{~S}$ rRNA gene sequencing, template DNA was prepared by using Prepman Ultra (Applied Biosystems). The 16S rRNA gene was amplified by using a universal set of primers (27f and 1492r) and sequenced directly, using a BigDye Terminator v3.1 cycle sequencing kit and an ABI PRISM 3100 Genetic Analyzer (Applied Biosystems). By BLAST search (Altschul et al., 1990) against the sequences available in GenBank/DDBJ, Lewinella persica (accession no. AF039295) was identified as the closest relative of strains MKG-38 ${ }^{\mathrm{T}}$ and $\mathrm{FYK} 2402 \mathrm{M} 69^{\mathrm{T}}$. Thus, pairwise comparison of the 16S rRNA gene sequences of strains MKG-38 ${ }^{\mathrm{T}}$ and FYK2402M $69^{\mathrm{T}}$ with those of type strains of species of the genus Lewinella and other related genera of the family 'Saprospiraceae' were performed by using the Needleman-Wunsch alignment algorithm (Needleman \& Wunsch, 1970; http://www.ebi.ac.uk/emboss/align/). Strains MKG-38 ${ }^{\mathrm{T}}$ and FYK2402M $69^{\mathrm{T}}$ shared sequence similarity of $86.4-92.7 \%$ with the members of the genus Lewinella, whereas they shared $<85 \%$ sequence similarity 
with members of other related genera (see Supplementary Table S1, available in IJSEM Online). The 16S rRNA gene sequences of the strains shown in Fig. 1 were aligned by using the CLUSTAL_X program (Thompson et al., 1997), and a phylogenetic tree was constructed by the neighbourjoining method (Saitou \& Nei, 1987). The robustness of the tree topology was calculated from bootstrap analysis using 1000 resamplings of the sequences (Felsenstein, 1985). Strains MKG-38 ${ }^{\mathrm{T}}$ and FYK2402M69 ${ }^{\mathrm{T}}$ clustered with the members of the genus Lewinella. L. persica was the closest relative of both strains, and the grouping was supported by high bootstrap values (Fig. 1).

Morphological, physiological and biochemical traits of strains MKG-38 $8^{\mathrm{T}}$ and FYK2402M69 ${ }^{\mathrm{T}}$, Lewinella cohaerens NBRC $102661^{\mathrm{T}}$, Lewinella nigricans NBRC $102662^{\mathrm{T}}$ and $L$. persica NBRC $102663^{\mathrm{T}}$ were characterized. The morphology of Gram-stained and unstained cells was observed under a light microscope, and that of cells negatively stained with $1 \%(\mathrm{w} / \mathrm{v})$ phosphotungstic acid was observed under a transmission electron microscope (H7600; Hitachi).

For most of the tests, cells grown on HSMA plates for 35 days at $25{ }^{\circ} \mathrm{C}$ were used unless stated otherwise. Gram reactions were performed as described by Cowan \& Steel (1993). The method described by Buck (1982) was also used for the differentiation of Gram-positive and Gramnegative bacteria. Gliding motility was examined in hanging drops of Marine Broth 2216 (MB; Difco) and on HSMA plates (Perry, 1973). Catalase activity was tested by mixing cells from colonies grown on HSMA plates with $3 \%(\mathrm{v} / \mathrm{v})$ hydrogen peroxide on a glass slide, whilst oxidase activity was tested by spotting the cells onto a cytochrome oxidase strip (Nissui Pharmaceuticals). Absorption spectra $(260-700 \mathrm{~nm})$ of acetone extracts of cells were recorded spectroscopically to examine the presence of carotenoidtype pigments. Bathochromic shift tests with $20 \%(\mathrm{w} / \mathrm{v})$ $\mathrm{KOH}$ were performed to test for the presence of flexirubintype pigments (Fautz \& Reichenbach, 1980). Growth at different temperatures $(4,10,15,20,25,30,35,37,40,42$ and $45^{\circ} \mathrm{C}$ ) was assessed on HSMA plates, whilst growth at different $\mathrm{pH}$ values was examined on HSMA plates or in $\mathrm{MB}$ with the final $\mathrm{pH}$ adjusted with either $\mathrm{HCl}(\mathrm{pH} 5$ and 6) or $\mathrm{NaOH}(\mathrm{pH} 8-10)$. Growth at high $\mathrm{NaCl}$ concentrations $[4-8 \%(\mathrm{w} / \mathrm{v}) \mathrm{NaCl}]$ was tested in $\mathrm{MB}$. Requirement of $\mathrm{NaCl}$ for growth was tested in one-fifth strength LuriaBertani (LB) medium containing 0,1 or $2 \%(\mathrm{w} / \mathrm{v}) \mathrm{NaCl}$ (Khan et al., 2007). Utilization of different nitrogen sources [sodium nitrate $\left(7.8 \mathrm{~g} \mathrm{l}^{-1}\right)$, ammonium sulphate $\left(7.8 \mathrm{~g} \mathrm{l}^{-1}\right)$, sodium glutamate $\left(20 \mathrm{~g} \mathrm{l}^{-1}\right)$, Casamino acids $\left(10 \mathrm{~g} \mathrm{l}^{-1}\right)$ and peptone $\left(10 \mathrm{~g} \mathrm{l}^{-1}\right)$ ] was tested in medium $\mathrm{N}$ (1.0 g glucose and $0.2 \mathrm{~g} \mathrm{NaHCO}_{3}$ dissolved in $11 \mathrm{ASW}$, $\mathrm{pH}$ 7.0). Methods described in detail elsewhere (Cowan \& Steel, 1993; Lewin \& Lounsbery, 1969; Smibert \& Krieg, 1981; Khan et al., 2007) were used to test the abilities of the strains to hydrolyse agar, carrageenan (type I; Sigma), casein, cellulose, chitin, CM-cellulose (High Viscosity; Sigma), DNA, gelatin, starch and Tweens 20, 40 and 80 . Indole production from tryptophan, acid production from glucose, hydrolysis of urea, aesculin and gelatin, and reduction of nitrate and nitrite by these strains were tested with the API 20NE system (bioMérieux), whilst their abilities to acidify different carbon sources were tested with the API $50 \mathrm{CH}$ system (bioMérieux) according to the

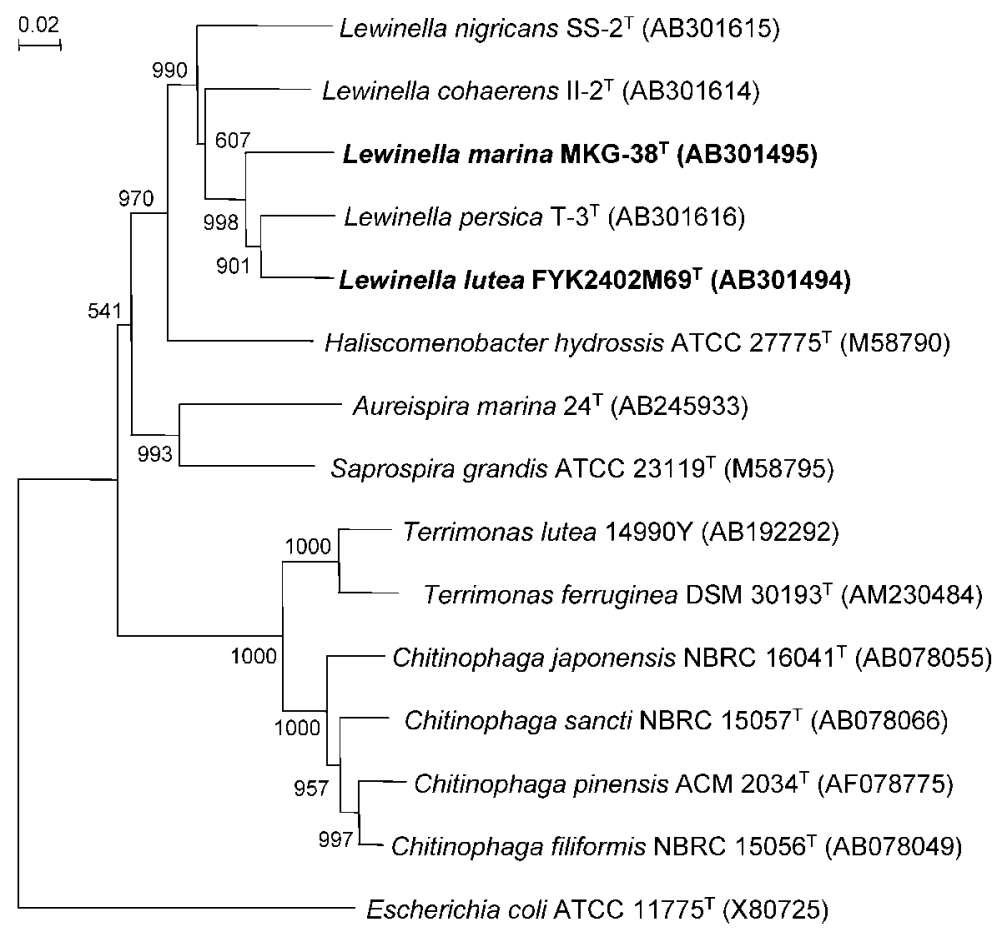

Fig. 1. Neighbour-joining tree showing the positions of strains MKG-38 ${ }^{\top}$ and FYK2402M69 ${ }^{\top}$ within the radiation of the genus Lewinella. Analysis was based on almost-complete 16S rRNA gene sequences. Numbers at nodes represent bootstrap values calculated from 1000 resamplings. Bar, $0.02 K_{\text {nuc }}$. 
manufacturer's instructions, except that inocula for API 20NE were prepared in ASW, whereas those for API $50 \mathrm{CH}$ were made in a 1:1 mixture of CHB medium (bioMérieux) and ASW. The API strips were incubated at $25{ }^{\circ} \mathrm{C}$ for $3-$ 4 days before test results were scored.

For fatty acid analysis, strains were grown on Marine Agar (MA; Difco) for 3-4 days at $25{ }^{\circ} \mathrm{C}$. Fatty acid profiles were determined by using the Sherlock microbial identification system (MIDI) according to the manufacturer's protocol (Sasser, 1990). Respiratory quinones were analysed by using the protocol of Nakagawa \& Yamasato (1993). Exponentially growing cells of strains $\mathrm{MKG}-38^{\mathrm{T}}$ and FYK2402M69 ${ }^{\mathrm{T}}$ in $\mathrm{MB}$ were used to prepare genomic DNA as described by Minamisawa (1990); the HPLC method of Mesbah et al. (1989) was used to determine the $\mathrm{G}+\mathrm{C}$ content of the DNA samples.

Morphological, physiological and chemotaxonomic characteristics of the strains are summarized in Tables 1 and 2 and in the genus and species descriptions. Although strains MKG-38 ${ }^{\mathrm{T}}$ and FYK2402M69 ${ }^{\mathrm{T}}$ formed a monophyletic clade with $L$. persica (Fig. 1), low $16 \mathrm{~S}$ rRNA gene sequence similarities $(<92.7 \%)$ and differences in phenotypic characteristics indicated clearly that strains $\mathrm{MKG}-38^{\mathrm{T}}$ and FYK2402M $69^{\mathrm{T}}$ cannot be assigned to any of the previously described species in the genus Lewinella. Therefore, the names Lewinella marina sp. nov. and Lewinella lutea sp. nov. are proposed to include strains $\mathrm{MKG}-38^{\mathrm{T}}$ and FYK2402M69 ${ }^{\mathrm{T}}$, respectively.

Originally, members of the genus Lewinella were described to be 2-3 $\mu \mathrm{m}$ in length (Sly et al., 1998). Strains MKG-38 ${ }^{\mathrm{T}}$ and FYK2402M69 ${ }^{\mathrm{T}}$, however, were smaller than $2 \mu \mathrm{m}$ in size (see Supplementary Fig. S1, available in IJSEM Online, and novel species descriptions below). In addition, members of the genus Lewinella have been described to be unable to degrade starch and cellulose (Sly et al., 1998). In contrast to the description, all strains studied were able to degrade starch, and strains $\mathrm{MKG}-38^{\mathrm{T}}$ and FYK2402M69 ${ }^{\mathrm{T}}$ were able to degrade CM-cellulose. Gliding motility has previously been observed in members of the genus Lewinella (Sly et al., 1998). However, in the present study, no gliding motility was observed in any of the strains studied. Thus, an emended description of the genus Lewinella is proposed. We also emend the species descriptions of L. cohaerens, L. nigricans and $L$. persica,

Table 1. Differentiating characteristics of the novel isolates and other species of the genus Lewinella

Taxa: 1, L. marina MKG-38 ${ }^{\mathrm{T}}$; 2, L. lutea FYK2402M69 ${ }^{\mathrm{T}}$; 3, L. cohaerens NBRC $102661^{\mathrm{T}} ; 4$, L. nigricans NBRC $102662^{\mathrm{T}} ; 5$, L. persica NBRC $102663^{\mathrm{T}}$. All strains tested positive for the presence of carotenoid-type pigments, degradation of DNA, starch, casein, gelatin, Tweens 20,40 and 80 , $\beta$ galactosidase and $\beta$-glucosidase, growth at $15-30{ }^{\circ} \mathrm{C}$, growth at $\mathrm{pH} 6-10$, growth in $1-5 \%(\mathrm{w} / \mathrm{v}) \mathrm{NaCl}$ and growth in $30-100 \%$ (v/v) seawater. All strains tested negative for flexirubin-type pigments, degradation of agar, cellulose, chitin and urea, reduction of nitrate and nitrite, indole production from tryptophan, acid production from glucose, arginine dihydrolase activity, growth at $45{ }^{\circ} \mathrm{C}$ and growth in $8 \% \mathrm{NaCl}(\mathrm{w} / \mathrm{v})$. + , Positive; -, negative; $(+)$, weakly positive; $v$, variable; tr, trace $(<1 \%$ of total).

\begin{tabular}{|c|c|c|c|c|c|}
\hline Characteristic & 1 & 2 & 3 & 4 & 5 \\
\hline Cell shape & $\begin{array}{l}\text { Short to } \\
\text { medium rods }\end{array}$ & $\begin{array}{l}\text { Short to } \\
\text { elongated rods }\end{array}$ & $\begin{array}{l}\text { Short to } \\
\text { elongated rods }\end{array}$ & $\begin{array}{l}\text { Short to } \\
\text { elongated rods }\end{array}$ & $\begin{array}{l}\text { Short to elongated rods; } \\
\text { clumps are formed }\end{array}$ \\
\hline Pigment & Dull orange & Dark orange & Light orange & Diffusible black & Dark orange \\
\hline CM-cellulose & + & + & - & - & - \\
\hline Casein & $(+)$ & $(+)$ & + & + & + \\
\hline \multicolumn{6}{|l|}{ Growth at: } \\
\hline pH 5.0 & $\mathrm{~V}$ & - & - & - & - \\
\hline $\mathrm{pH} 9.0$ & + & + & $(+)$ & $(+)$ & $(+)$ \\
\hline $\mathrm{pH} 10.0$ & + & $(+)$ & $(+)$ & $(+)$ & $(+)$ \\
\hline $4{ }^{\circ} \mathrm{C}$ & + & - & - & - & - \\
\hline $35^{\circ} \mathrm{C}$ & + & + & - & + & - \\
\hline $37^{\circ} \mathrm{C}$ & + & - & - & - & - \\
\hline $42{ }^{\circ} \mathrm{C}$ & + & - & - & - & - \\
\hline Growth in $7 \% \mathrm{NaCl}$ & + & - & - & - & - \\
\hline \multicolumn{6}{|c|}{ Cellular fatty acids ( $\%$ of total) } \\
\hline C15:0 & $\operatorname{tr}$ & $\operatorname{tr}$ & 13 & 6 & $\operatorname{tr}$ \\
\hline $\mathrm{i}-\mathrm{C} 17: 1 \omega 9 c$ & 23 & 9 & $\operatorname{tr}$ & 2 & 10 \\
\hline Summed feature $3^{\star}$ & 23 & 53 & $\operatorname{tr}$ & 9 & 30 \\
\hline $\begin{array}{l}\text { DNA G + C content } \\
(\mathrm{mol} \%)\end{array}$ & 61 & 56 & $45 \dagger$ & $53 \dagger$ & $53 \dagger$ \\
\hline
\end{tabular}

${ }^{\star}$ Summed feature 3 comprises i-C15:0 2-OH and/or C16:1 $107 c$.

$\dagger$ DNA G + C content data for L. cohaerens, L. nigricans and L. persica are from Sly et al. (1998). 
Table 2. Comparision of cellular fatty acid profiles of novel strains isolated during this study and of previously reported species of the genus Lewinella

Taxa: 1, L. marina MKG-38 $8^{\mathrm{T}}$; 2, L. lutea FYK2402M69 ${ }^{\mathrm{T}} ; 3, L$. cohaerens $\mathrm{NBRC} 102661^{\mathrm{T}} ; 4$, L. nigricans NBRC $102662^{\mathrm{T}} ; 5$, L. persica NBRC $102663^{\mathrm{T}}$. tr, Trace $(<1 \%$ of total).

\begin{tabular}{|lrrrrr|}
\hline Fatty acid & $\mathbf{1}$ & $\mathbf{2}$ & $\mathbf{3}$ & $\mathbf{4}$ & $\mathbf{5}$ \\
\hline $\mathrm{C} 15: 0$ & $\operatorname{tr}$ & $\operatorname{tr}$ & 13 & 6 & $\operatorname{tr}$ \\
i-C15:0 & 22 & 16 & 30 & 32 & 28 \\
i-C15:0 3-OH & 2 & 4 & 3 & 2 & 2 \\
i-C15: 1 & 3 & 2 & 29 & 19 & 4 \\
C15: $1 \omega 6 c$ & 1 & 2 & - & - & 2 \\
C15: $1 \omega 8 c$ & - & - & - & - & 2 \\
C16:0 & 4 & 3 & $\operatorname{tr}$ & 7 & 2 \\
i-C16:0 & - & - & 3 & 3 & $\operatorname{tr}$ \\
i-C16:1 & - & 1 & 1 & - & $\operatorname{tr}$ \\
C16: $1 \omega 5 c$ & - & - & 2 & - & $\operatorname{tr}$ \\
C16: $1 \omega 7 c$ alcohol & $\operatorname{tr}$ & - & - & 1 & $\operatorname{tr}$ \\
C16: $1 \omega 11 c$ & - & - & - & 2 & - \\
i-C17:0 & 4 & 1 & 2 & $\operatorname{tr}$ & $\operatorname{tr}$ \\
i-C17:0 3-OH & 6 & 4 & 3 & 6 & 5 \\
C17: $1 \omega 6 c$ & 3 & 2 & $\operatorname{tr}$ & $\operatorname{tr}$ & 5 \\
C17: $1 \omega 9 c$ & - & - & - & 1 & - \\
i-C17: $1 \omega 9 c$ & 23 & 9 & $\operatorname{tr}$ & 2 & 10 \\
C18: $1 \omega 7 c$ & 2 & - & - & - & 1 \\
C19:0 $10-$ methyl & 1 & - & - & - & 2 \\
Summed feature $3 *$ & 23 & $53 \dagger$ & $\operatorname{tr}$ & 9 & 30 \\
Summed feature $4^{*}$ & $\operatorname{tr}$ & - & 2 & - & $\operatorname{tr}$ \\
Unknown & 2 & 3 & 3 & 2 & 3 \\
& & & & & \\
\hline
\end{tabular}

${ }^{*}$ Summed feature 3 comprises i-C15:0 $2-\mathrm{OH}$ and/or $\mathrm{C} 16: 1 \omega 7 c$; summed feature 4 comprises i-C17:1 and/or a-C17:1.

$\dagger$ Two peaks for summed feature 3 were detected.

because detailed phenotypic characteristics of these strains were obtained for the first time in this study.

\section{Emended description of the genus Lewinella Sly et al. 1998}

Lewinella (Le.wi.nel'la. L. dim. ending -ella; N.L. fem. dim. n. Lewinella named after Professor Ralph Lewin, who first isolated these organisms).

Cells are Gram-negative, aerobic, chemo-organotrophic, asporogenic rods that are $0.7-3.0 \mu \mathrm{m}$ in length and 0.3 $0.7 \mu \mathrm{m}$ in width; often elongated to a filament of 5-25 $\mu \mathrm{m}$ in length. Carotenoid-type pigments are produced; flexirubin-type pigments are not. Oxidase- and catalasepositive. Major respiratory quinone is MK-7. Major cellular fatty acids are i-C15:0, either i-C15:1 or i$\mathrm{C} 17: 1 \omega 9 c$ and either $\mathrm{C} 15: 0$ or summed feature 3 (i-C15:0 2-OH and/or $\mathrm{C} 16: 1 \omega 7 c)$. Members of the genus are marine bacteria that require $\mathrm{NaCl}$ for growth. Nitrate and nitrite are not reduced. Indole is not produced from tryptophan. The DNA G $+\mathrm{C}$ content is $45-61 \mathrm{~mol} \%$.

The type species of the genus is Lewinella cohaerens.

\section{Emended description of Lewinella cohaerens (Lewin 1970) Sly et al. 1998}

Lewinella cohaerens (co.hae'rens. L. part. adj. cohaerens coherent, uniting together).

The species possesses the following characteristics in addition to those described for the genus. Cells are rodshaped, $1.2-2.0 \mu \mathrm{m}$ in length and $0.3-0.5 \mu \mathrm{m}$ in width, often elongated to a long filament of $5-15 \mu \mathrm{m}$ in length. Colonies on MA are light orange. Growth occurs at 10$30{ }^{\circ} \mathrm{C}$ (optimally at $25{ }^{\circ} \mathrm{C}$ ). Growth does not occur at $4{ }^{\circ} \mathrm{C}$ or at $35{ }^{\circ} \mathrm{C}$ or higher. Growth occurs at $\mathrm{pH}$ 6-8 (optimally at $\mathrm{pH}$ 7). Weak growth is observed at $\mathrm{pH} 9$ and 10 . Growth does not occur at $\mathrm{pH} 5$. Growth occurs with $2-4 \%(\mathrm{w} / \mathrm{v})$ $\mathrm{NaCl}$; weak growth is observed with $5 \%(\mathrm{w} / \mathrm{v}) \mathrm{NaCl}$. Growth does not occur with 0,1 or $6 \%(\mathrm{w} / \mathrm{v}) \mathrm{NaCl}$ or higher. Positive for degradation of casein, DNA, gelatin, starch and Tweens 20, 40 and 80. Negative for degradation of agar, carrageenan, cellulose, chitin, CM-cellulose and urea. $\beta$-Galactosidase and $\beta$-glucosidase are positive, but arginine dihydrolase is negative. Casamino acids and peptone are utilized as nitrogen sources, but ammonium sulphate, sodium glutamate and sodium nitrate are not. Acid is produced from D-cellobiose, D-glucose, D-lactose, D-lyxose, D-turanose, aesculin and gentiobiose. Acid production is weak from amygdalin, arbutin, D-fucose, Dmelezitose, D-tagatose, L-fucose and methyl- $\alpha$-D-glucopyranoside. Major cellular fatty acids are i-C15:0, i-C15: 1 and C15:0. The DNA G $+\mathrm{C}$ content is $45 \mathrm{~mol} \%$.

The type strain is $\mathrm{II}-2^{\mathrm{T}} \quad\left(=\mathrm{NBRC} 102661^{\mathrm{T}}=\mathrm{NCIMB}\right.$ $\left.12855^{\mathrm{T}}\right)$. Isolated from beach sand at Biarritz, France.

\section{Emended description of Lewinella nigricans (Lewin 1970) Sly et al. 1998}

Lewinella nigricans (ni'gri.cans. L. part. adj. nigricans blackening).

The species possesses the following characteristics in addition to those described for the genus. Cells are rodshaped, $1.5-3.0 \mu \mathrm{m}$ in length and $0.3-0.6 \mu \mathrm{m}$ in width, often elongated to a filament of $5-25 \mu \mathrm{m}$ in length. Colonies on MA produce black pigments. Growth occurs at $15-37{ }^{\circ} \mathrm{C}$ (optimally at $25-30{ }^{\circ} \mathrm{C}$ ). Growth does not occur at 4,10 or $40{ }^{\circ} \mathrm{C}$ or higher. Growth occurs at $\mathrm{pH} 6-8$ (optimally at pH 7). Weak growth is observed at $\mathrm{pH} 9$ and 10 . Growth does not occur at $\mathrm{pH} 5$. Growth occurs with 2$4 \%(\mathrm{w} / \mathrm{v}) \mathrm{NaCl}$; weak growth is observed with $5 \%(\mathrm{w} / \mathrm{v})$ $\mathrm{NaCl}$. Growth does not occur with 0 or $1 \%(\mathrm{w} / \mathrm{v}) \mathrm{NaCl}$. Positive for degradation of casein, DNA, gelatin, starch and Tweens 20, 40 and 80. Negative for degradation of agar, carrageenan, cellulose, chitin, CM-cellulose and urea. $\beta$ Galactosidase and $\beta$-glucosidase are positive, but arginine dihydrolase is negative. Casamino acids and peptone are utilized as nitrogen sources, but ammonium sulphate, sodium glutamate and sodium nitrate are not. Acid is produced from starch, D-arabinose, D-cellobiose, D-galactose, D-glucose, D-lactose, D-maltose, D-melibiose, 
D-melezitose, D-raffinose, D-sucrose, D-trehalose, D-turanose, D-xylose, aesculin, glycogen, L-arabinose, L-rhamnose, salicin and xylitol. Acid production is weak from amygdalin, arbutin, D-lyxose, D-fucose, D-mannose, L-fucose, methyl- $\alpha$-D-glucopyranoside, methyl- $\alpha$-D-mannopyranoside, methyl- $\beta$-D-xylopyranoside and $N$-acetylglucosamine. Major fatty acids are i-C15:0, i-C15:1 and summed feature 3 (i-C15:0 2-OH and/or C16:1 $1 \omega 7 c$ ). The DNA $\mathrm{G}+\mathrm{C}$ content is $53 \mathrm{~mol} \%$.

The type strain is SS- $2^{\mathrm{T}}\left(=\mathrm{NBRC} 102662^{\mathrm{T}}=\mathrm{NCIMB}\right.$ $\left.1420^{\mathrm{T}}\right)$. Isolated from beach sand near Lagos, Nigeria.

\section{Emended description of Lewinella persica (Lewin 1970) Sly et al. 1998}

Lewinella persica [per'si.ca. L. adj. persica Persian (of peach), i.e. peach-coloured].

The species possesses the following characteristics in addition to those described for the genus. Cells are rodshaped, $1.5-3.0 \mu \mathrm{m}$ in length and $0.3-0.5 \mu \mathrm{m}$ in width, often elongated to a filament of $5-17 \mu \mathrm{m}$ in length. Cells adhere to each other, forming clumps. Colonies on MA are dark orange. Growth occurs at $4-30{ }^{\circ} \mathrm{C}$ (optimally at $25{ }^{\circ} \mathrm{C}$ ). Growth does not occur at $35{ }^{\circ} \mathrm{C}$ or higher. Growth occurs at $\mathrm{pH}$ 6-8 (optimum at $\mathrm{pH} 7$ ). Weak growth is observed at $\mathrm{pH} 9$ and 10. Growth does not occur at $\mathrm{pH} 5$. Growth occurs with $2-4 \%(\mathrm{w} / \mathrm{v}) \mathrm{NaCl}$; weak growth is observed with $5 \%(w / v) ~ N a C l$. Growth does not occur with 0,1 or $6 \%(\mathrm{w} / \mathrm{v}) \mathrm{NaCl}$ or higher. Positive for degradation of casein, DNA, gelatin, starch and Tweens 20, 40 and 80 . Negative for degradation of agar, carrageenan, cellulose, chitin and urea. $\beta$-Galactosidase and $\beta$-glucosidase are positive, but arginine dihydrolase is negative. Casamino acids and peptone are used as nitrogen sources, but ammonium sulphate, sodium glutamate and sodium nitrate are not. Acid is produced from D-galactose, Draffinose, L-rhamnose, aesculin and gentiobiose. Acid production is weak from amygdalin, D-adonitol, Dcellobiose, D-fructose, D-glucose, D-lactose, D-mannose, D-ribose, D-sucrose, erythritol, L-fucose, methyl- $\alpha$-D-glucopyranoside and methyl- $\beta$-D-xylopyranoside. Major cellular fatty acids are i-C15:0, summed feature 3 (i-C15:0

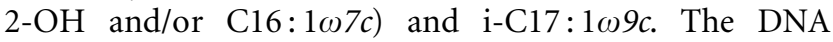
$\mathrm{G}+\mathrm{C}$ content is $53 \mathrm{~mol} \%$.

The type strain is $\mathrm{T}-3^{\mathrm{T}} \quad\left(=\mathrm{NBRC} \quad 102663^{\mathrm{T}}=\mathrm{NCIMB}\right.$ $\left.1396^{\mathrm{T}}\right)$. Isolated from brown mud, Galway, Ireland.

\section{Description of Lewinella marina sp. nov.}

Lewinella marina (ma.ri'na. L. fem. adj. marina of the sea, marine).

The species possesses the following characteristics in addition to those described for the genus. Cells are short rods, $0.6-1.0 \mu \mathrm{m}$ in length and $0.4-0.5 \mu \mathrm{m}$ in width. Colonies on MA are semi-dry and dull orange. Growth occurs at $4-42{ }^{\circ} \mathrm{C}$ (optimally at $25-30{ }^{\circ} \mathrm{C}$ ). Growth does not occur at $45{ }^{\circ} \mathrm{C}$. Growth occurs at pH 6-10 (optimally at $\mathrm{pH} 7-8$ ). Weak growth is observed at $\mathrm{pH}$. Growth is observed with $1-7 \%(\mathrm{w} / \mathrm{v}) \mathrm{NaCl}$ [optimally with $2-4 \%$ $(\mathrm{w} / \mathrm{v}) \mathrm{NaCl}$. Positive for degradation of DNA, CMcellulose, gelatin, starch and Tweens 20, 40 and 80 . Casein degradation activity is weak. Negative for degradation of agar, carrageenan, cellulose, chitin and urea. $\beta$ Galactosidase and $\beta$-glucosidase are positive, but arginine dihydrolase is negative. Casamino acids and peptone are utilized as nitrogen sources, but ammonium sulphate, sodium glutamate and sodium nitrate are not. Acid is produced from amygdalin, arbutin, D-arabinose, D-cellobiose, D-fructose, D-galactose, D-glucose, D-lactose, Dlyxose, D-maltose, D-melibiose, D-mannose, D-melezitose, D-raffinose, D-sucrose, D-trehalose, D-turanose, D-xylose, gentiobiose, aesculin, L-arabinose, L-fucose, L-rhamnose, methyl- $\alpha$-D-glucopyranoside, methyl- $\alpha$-D-mannopyranoside, methyl- $\beta$-D-xylopyranoside, $N$-acetylglucosamine and salicin. Acid production is weak from starch, D-fucose, D-ribose, D-tagatose, L-sorbose, L-xylose and inulin. The major cellular fatty acids are $\mathrm{i}-\mathrm{C} 15: 0$, summed feature 3 (i$\mathrm{C} 15: 02-\mathrm{OH}$ and/or $16: 1 \omega 7 c$ ) and $\mathrm{i}-\mathrm{C} 17: 1 \omega 9 c$. The DNA $\mathrm{G}+\mathrm{C}$ content is $61 \mathrm{~mol} \%$.

The type strain is MKG- $38^{\mathrm{T}}\left(=\mathrm{NBRC} 102633^{\mathrm{T}}=\mathrm{NCIMB}\right.$ $\left.14312^{\mathrm{T}}\right)$. Isolated from a marine sediment sample of Kamogawa city, Japan.

\section{Description of Lewinella lutea sp. nov.}

Lewinella lutea (lu.te' a. L. fem. adj. lutea orange-coloured).

The species possesses the following characteristics in addition to those described for the genus. Cells are short rods, $0.6-1.0 \mu \mathrm{m}$ in length and $0.3-0.5 \mu \mathrm{m}$ in width, often elongated to a filament of $5-20 \mu \mathrm{m}$ in length. Colonies on MA are dark orange. Growth occurs at $10-35{ }^{\circ} \mathrm{C}$ (optimally at $25{ }^{\circ} \mathrm{C}$ ). Growth does not occur at 4 or $37{ }^{\circ} \mathrm{C}$ or higher. Growth occurs at $\mathrm{pH}$ 6-8 (optimally at $\mathrm{pH} 7$ ). Growth does not occur at $\mathrm{pH} 4$ or 5 . Weak growth is observed at pH 9 and 10. Growth occurs with 2-4\% (w/v) NaCl; weak growth is observed with $5 \%(\mathrm{w} / \mathrm{v}) \mathrm{NaCl}$. Growth does not occur with $6 \%(\mathrm{w} / \mathrm{v}) \mathrm{NaCl}$ or higher. Positive for the degradation of CM-cellulose, DNA, gelatin, starch and Tweens 20, 40 and 80. Casein degradation activity is weak. Negative for degradation of agar, carrageenan, chitin, cellulose and urea. $\beta$-Galactosidase and $\beta$-glucosidase are positive, but arginine dihydrolase is negative. Casamino acids and peptone are utilized as nitrogen sources, but ammonium sulphate, sodium glutamate and sodium nitrate are not. Acid is produced from amygdalin, arbutin, D-cellobiose, D-fructose, D-galactose, D-glucose, D-lactose, D-maltose, D-mannose, D-melibiose, D-raffinose, D-sucrose, D-trehalose, D-turanose, D-xylose, gentiobiose, L-rhamnose, methyl- $\alpha$-D-glucopyranoside, methyl- $\alpha$-D-mannopyranoside, methyl- $\beta$-D-xylopyranoside, $\quad N$-acetylglucosamine and salicin. Acid production is weak from starch, Dfructose, D-melezitose and L-fucose. The major cellular fatty acids are summed feature 3 (i-C15:0 $2-\mathrm{OH}$ and/or 
$\mathrm{C} 16: 1 \omega 7 c)$, i-C15:0 and i-C17: $1 \omega 9 c$. The DNA G+C content is $56 \mathrm{~mol} \%$.

The type strain is FYK2402M69 ${ }^{\mathrm{T}}\left(=\mathrm{NBRC} 102634^{\mathrm{T}}=\right.$ NCIMB $14313^{\mathrm{T}}$ ). Isolated from a marine snail collected from Mikurajima island, Japan.

\section{Acknowledgements}

This work was supported by the New Energy and Industrial Technology Development Organization (NEDO; grant no. 04000182-0). The authors would like to thank Ms Mai Takahashi for providing $16 \mathrm{~S}$ rRNA gene sequences of Lewinella species and $\mathrm{Mr}$ Motoyuki Ohuchi for technical assistance.

\section{References}

Altschul, S. F., Gish, W., Miller, W., Myers, E. W. \& Lipman, D. J. (1990). Basic local alignment search tool. J Mol Biol 215, 403-410.

Buck, J. D. (1982). Nonstaining (KOH) method for determination of Gram reactions of marine bacteria. Appl Environ Microbiol 44, 992-993.

Cowan, S. T. \& Steel, K. J. (1993). Manual for the Identification of Medical Bacteria, 3rd edn. London: Cambridge University Press.

Fautz, E. \& Reichenbach, H. (1980). A simple test for flexirubin-type pigments. FEMS Microbiol Lett 8, 87-91.

Felsenstein, J. (1985). Confidence limits on phylogenies: an approach using the bootstrap. Evolution 39, 783-791.

Khan, S. T., Nakagawa, Y. \& Harayama, S. (2007). Sediminibacter furfurosus gen. nov., sp. nov. and Gilvibacter sediminis gen. nov., sp. nov., novel members of the family Flavobacteriaceae. Int J Syst Evol Microbiol 57, 265-269.

Lewin, R. A. (1970). New Herpetosiphon species (Flexibacterales). Can J Microbiol 16, 517-520.
Lewin, R. A. \& Lounsbery, D. C. (1969). Isolation, cultivation and characterization of flexibacteria. J Gen Microbiol 58, 145-170.

Mesbah, M., Premachandran, U. \& Whitman, W. B. (1989). Precise measurement of the $\mathrm{G}+\mathrm{C}$ content of deoxyribonucleic acid by highperformance liquid chromatography. Int J Syst Bacteriol 39, 159-167.

Minamisawa, K. (1990). Division of rhizobitoxine-producing and hydrogen-uptake positive strains of Bradyrhizobium japonicum by nifDKE sequence divergence. Plant Cell Physiol 31, 81-89.

Nakagawa, Y. \& Yamasato, K. (1993). Phylogenetic diversity of the genus Cytophaga revealed by $16 \mathrm{~S}$ rRNA sequencing and menaquinone analysis. J Gen Microbiol 139, 1155-1161.

Needleman, S. B. \& Wunsch, C. D. (1970). A general method applicable to the search for similarities in the amino acid sequence of two proteins. J Mol Biol 48, 443-453.

Perry, L. B. (1973). Gliding motility in some non-spreading flexibacteria. J Appl Bacteriol 36, 227-232.

Saitou, N. \& Nei, M. (1987). The neighbor-joining method: a new method for reconstructing phylogenetic trees. Mol Biol Evol 4, 406-425.

Sasser, M. (1990). Identification of bacteria by gas chromatography of cellular fatty acids, MIDI Technical Note 101. Newark, DE: MIDI Inc. http://www.midi-inc.com/media/pdfs/TechNote_101.pdf

Sly, L. I., Taghavi, M. \& Fegan, M. (1998). Phylogenetic heterogeneity within the genus Herpetosiphon: transfer of the marine species Herpetosiphon cohaerens, Herpetosiphon nigricans and Herpetosiphon persicus to the genus Lewinella gen. nov. in the FlexibacterBacteroidetes-Cytophaga phylum. Int J Syst Bacteriol 48, 731-737.

Smibert, R. M. \& Krieg, N. R. (1981). General characterization. In Manual of Methods for General Bacteriology, pp. 409-443. Edited by P. Gerhardt, R. G. E. Murray, R. N. Costilow, E. W. Nester, W. A. Wood, N. R. Krieg \& G. B. Phillips. Washington, DC: American Society for Microbiology.

Thompson, J. D., Gibson, T. J., Plewniak, F., Jeanmougin, F. \& Higgins, D. G. (1997). The CLUSTAL_X windows interface: flexible strategies for multiple sequence alignment aided by quality analysis tools. Nucleic Acids Res 25, 4876-4882. 